\title{
Pengaruh Lingkungan Belajar dan Minat Belajar Terhadap Hasil Belajar Matematika Siswa Kelas VII Semester Genap SMPN 3 Tungkal Ulu di Masa Pandemi COVID-19
}

\author{
Kurnia Prantauwati ${ }^{1}$, Syaiful ${ }^{2}$, Maison ${ }^{3}$ \\ 1, 2, 3 Program Studi Pendidikan Matematika, Fakultas Keguruan dan Ilmu Pendidikan, Universitas Jambi, \\ Jl. Raden Mattaher No. 16-Jambi, Kota Jambi, Indonesia \\ Kurniaprantauwati94@gmail.com
}

\begin{abstract}
This study aims to determine the effect of the learning environment and interest in learning on students' mathematics learning outcomes during the COVID-19 pandemic. The research method used is non-experimental quantitative research with ex-post-facto. Data collection techniques in this study were tests and questionnaires. Data analysis was carried out with prerequisite tests consisting of normality, linearity, and independent tests. Furthermore, hypothesis testing was carried out with multiple regression analysis. Based on the results of the analysis, it was found that there was a positive and significant influence between the learning environment at home and interest in learning with the mathematics learning outcomes of class VII students of SMP Negeri 3 Tungkal Ulu in the Even Semester of the 2020/2021 Academic Year. This is indicated by the -F test which is $6,593277831>3,35$. The multiple correlation coefficient $(\mathrm{R})$ is 0,5728293921 and the coefficient of determination 0,3281335125 with the linear equation $\widehat{Y}=-38,333043313+0,4186176102 \mathrm{X}_{1}+$ $0,9070199850 X_{2}$. The relative contribution of $X_{1}$ is $35,9591 \%$ and $X_{2}$ is $64,0409 \%$ and the effective contribution $\mathrm{X}_{1}$ is $11,7994 \%$ and $\mathrm{X}_{2}$ is $21,01395 \%$.
\end{abstract}

Keywords: Learning Environment, Learning Interests, Mathematics Learning Outcomes, COVID-19 Pandemic

\begin{abstract}
Abstrak
Penelitian ini bertujuan untuk mengetahui pengaruh lingkungan belajar dan minat belajar terhadap hasil belajar matematika peserta didik di masa pandemic COVID-19. Metode penelitian yang digunakan adalah penelitian kuantitatif non eksperimen dengan ex-post-facto. Teknik pengumpulan data pada penelitian ini adalah tes dan angket. Analisis data dilakukan dengan uji prasyarat terdiri dari uji normalitas, linieritas, dan indepen. Selanjutnya dilakukan uji hipotesis dengan analisis regresi ganda. Berdasarkan hasil analisis diperoleh terdapat pengaruh yang positif dan signifikan antara lingkungan belajar di rumah dan minat belajar dengan hasil belajar matematika siswa kelas VII SMP Negeri 3 Tungkal Ulu Semester Genap Tahun Ajaran 2020/2021. Hal ini ditunjukkan dengan uji $-F$ yaitu 6,593277831 $>3,35$. Koefisien korelasi ganda $(R)$ sebesar 0,5728293921 dan koefisien determinasi $\left(R^{2}\right)$ sebesar 0,3281335125 dengan persamaan garis linear $\widehat{\mathrm{Y}}=-38,333043313+$ $0,4186176102 \mathrm{X}_{1}+0,9070199850 \mathrm{X}_{2}$. Besar sumbangan relatif $\mathrm{X}_{1}$ sebesar 35,9591\% dan $\mathrm{X}_{2}$ sebesar $64,0409 \%$ serta sumbangan efektif $\mathrm{X}_{1}$ sebesar $11,7994 \%$ dan $\mathrm{X}_{2}$ sebesar $21,01395 \%$.
\end{abstract}

Kata kunci: Lingkungan Belajar, Minat Belajar, Hasil Belajar Matematika, Pandemi COVID-19

Copyright (c) 2021 Kurnia Prantauwati, Syaiful, Maison

$\triangle$ Corresponding author: Kurnia Prantauwati

Email Address: kurniaprantauwati94@gmail.com (Jl. Raden Mattaher No. 16-Jambi, Kota Jambi, Indonesia) Received 15 Agustus 2021, Accepted 29 September 2021, Published 29 September 2021

\section{PENDAHULUAN}

Dunia diresahkan dengan munculnya pandemic Covid-19 yang disebabkan oleh penyebaran virus corona. Pandemic virus corona di tahun 2020 selain mengganggu stabilitas perekonomian juga mempengaruhi sistem dibidang pendidikan setiap wilayah di Indonesia. Salah satu kebijakan pada bidang pendidikan yaitu dengan menggantikan sementara kegiatan pembelajaran di kelas. Kebijakan tersebut dilakukan diseluruh sekolah dan perguruan tinggi di Indonesia, pemerintah memberikan solusi agar kegiatan belajar mengajar tetap berjalan sebagaimana mestinya dengan menggunakan alternative program pembelajaran jarak jauh dengan menggunakan media pembelajaran daring dan aplikasi- 
aplikasi yang dapat digunakan oleh guru dan siswa. Program tersebut dapat membantu pengajar menjangkau para siswa dari jarak jauh dan mengurangi hambatan pada bidang pendidikan.

Sesuai dengan surat edaran Kementerian Pendidikan dan Kebudayaan (Kemendikbud) No. 4 tahun 2020 tentang pelaksanaan kebijakan pendidikan dalam masa darurat penyebaran Coronavirus Disesase (Covid-19) terkait proses belajar menyatakan bahwa belajar dari rumah melalui pembelajaran daring/jarak jauh dilaksanakan untuk memberikan pembelajaran yang bermakna bagi siswa. Kondisi ini juga tentu tidak mudah dilalui oleh masyarakat, di mana orang tua ikut berperan sebagai guru atau pengajar ketika belajar di dalam rumah(MENDIKBUD, 2020). Siswa diberikan 2 tugas sebagai sarana untuk mengetahui pencapaian atau penilaian kemampuan siswa. Adapun kecemasan pada diri siswa di mana tugas yang diberikan oleh guru sebagai kegiatan memindahkan aktivitas kelas dari belajar di sekolah menjadi belajar di rumah dibebankan pada siswa bahkan lebih banyak. Selain itu, sekolah tetap melakukan kegiatan penilaian untuk kepentingan rapor kenaikan kelas pada tiap-tiap kelas.

Belajar dan pembelajaran adalah dua hal yang saling berhubungan erat dan tidak dapat dipisahkan dalam kegiatan edukatif. Kegiatan belajar mengajar yang dilakukan dalam hal ini diarahkan untuk mencapai tujuan tertentu yang telah dirumuskan sebelum pengajaran dilakukan. Guru secara sadar merencanakan kegiatan pengajarannya secara sistematis dengan memanfaatkan segala sesuatunya untuk kepentingan dalam pengajaran. (Sukardi, 2016; aprida Pane,2003)(aprida Pane, 2003)

Dalam proses pembelajaran, unsur proses belajar memegang peranan yang penting. Keberhasilan siswa dalam mengikuti program pendidikan di sekolah dilihat berdasarkan hasil belajarnya. Hasil belajar merupakan tolok ukur maksimal yang telah dicapai siswa setelah melakukan proses belajar. Biasanya dalam kegiatan belajar mengajar di sekolah setelah berakhirnya belajar untuk mengetahui tingkat keberhasilan diadakan pengukuran atau evaluasi dan hasil tersebut yang disebut hasil belajar.

Hasil belajar adalah seluruh kecakapan dan hasil yang dicapai melalui proses belajar mengajar di sekolah yang dinyatakan dengan angka-angka atau nilai-nilai berdasarkan tes hasil belajar. Sedangkan menurut Gagne dan Driscoll hasil belajar adalah kemampuan-kemampuan yang dimiliki siswa sebagai akibat perbuatan belajar dan dapat diamati melalui penampilan siswa(Andrini, 2016). Berdasarkan observasi yang dilakukan di SMPN 3 Tungkal Ulu pada tahun ajaran 2020/2021 semester ganjil, hasil belajar siswa masih rendah. Nilai ujian matematika Siswa kelas VII Semester Ganjil siswa SMP Negeri 3 Tungkal Ulu tahun ajaran 2020/2021 dapat dilihat pada tabel berikut.

Tabel 1. Nilai Ujian Matematika Kelas VII Semeter Ganjil

\begin{tabular}{|l|l|l|l|l|}
\hline No & Kelas & Jumlah Siswa & Nilai $\geq \mathbf{6 5}($ Lulus KKM) & Nilai $<\mathbf{6 5}$ \\
\hline 1 & VII A & 27 & 9 & 18 \\
\hline 2 & VII B & 29 & 11 & 18 \\
\hline 3 & VII C & 30 & 13 & 17 \\
\hline 4 & VII D & 31 & 10 & 20 \\
\hline
\end{tabular}


Sumber SMP Negeri 3Tungkal Ulu Tahun Ajaran 2020/2021

Berdasarkan tabel di atas, tampak bahwa hasil Ujian Semester Ganjil matematika kelas VII SMP N 3 Tungkal Ulu masih rendah. Sebagian besar siswa masih belum mencapai Kriteria Ketuntasan Minimal (KKM) yaitu 65. Hal ini menunjukkan bahwa hasil belajar matematika siswa masih rendah, rendahnya hasil Ujian Semester Ganjil matematika siswa disebabkan karena adanya kesulitan dalam belajar matematika yang dipengaruhi oleh beberapa hal. untuk mengatasi hal tersebut perlu ditelusuri faktor-faktor yang diduga mempengaruhi hasil belajar matematika.

Faktor yang diduga berpengaruh dalam pencapaian hasil belajar adalah lingkungan belajar, khususnya lingkungan belajar dirumah saat pembelajaran online. Jika dikaitan dengan pendapat idola, Afriza \& Khairani mengemukakan bahwa keadaan lingkungan fisik sekolah harus nyaman, aman, tenang, bersih dapat meningkatkan gairah dan semangat dalam belajar (Idola, Sano, \& Khairani, 2016). Dalam penelitian ini, lingkungan belajar di rumah menjadi perhatian karena sangat dekat dengan kehidupan siswa, lingkungan belajar di rumah yang kurang mendukung serta kurang nyaman pada masa pandemi mengakibatkan siswa malas untuk belajar. Kurangnya motivasi orang tua serta dukungan dari orang tua, membuat siswa kurang termotivasi untuk belajar.

Berdasarkan informasi dari beberapa siswa SMP N 3 Tungkal Ulu, lingkungan belajar dirumah siswa kurang nyaman digunakan untuk belajar. Sehingga siswa lebih suka menonton televisi, bermain gadget atau bermain bersama teman. Hasil wawancara dengan sebagian siswa kelas VII mengatakan bahwa orang tua mereka sibuk bekerja, sehingga kurang memeperhatikan belajar siswa. Saat ini juga dikeluhkan oleh para orangtua, bahwa saat mendampingi siswa belajar di rumah merupakan beban tersendiri bagi orang tua yang tidak memiliki latar belakang pendidikan yang cukup ataupun sarana dan fasilitas yang memadai.

Selain faktor lingkungan belajar siswa, minat belajar di duga salah satu faktor yang berasal dari dalam diri siswa yang diduga dapat mempengaruhi dalam pencapaian hasil belajar. Minat adalah suatu rasa lebih suka dan rasa ketertarikan pada suatu hal atau aktivitas, tanpa ada yang menyuruh. Minat belajar tumbuh atas dasar kesadaran dan bukan atas dorongan yang bersifat keterpaksaan (Slameto, 3004). Indikator minat ada empat, yaitu: perasaan senang, ketertarikan siswa, perhatian siswa dan keterlibatan siswa(Safari, 2003). Minat belajar siswa pada masa pandemi kurang maksimal, dikarenakan kurangnya pemahaman belajar siswa dalam pembelajaran online.

Pembelajaran Online dikenal juga dengan istilah pembelajaran elektronik, e-learning, on-line learning, virtual learling, online learning merupakan proses belajar mengajar yang memanfaat kan internet dan media digital dalam penyampaian materinya. Pembelajaran online memiliki beberapa dampak postif bagi siswa dan guru karena siswa dan guru dapat belajar dan mengajar dimana saja dan kapan saja. (Patria, L \& Yulianto, K, 2011). 
Akan tetapi, ada permasalahan yang dapat mengganggu proses pembelajaran online yaitu siswa memiliki minat dan semangat belajar yang kurang ketika menjalankan pembelajaran online, padahal minat belajar merupakan hal penting dalam proses belajar. Minat dalam belajar memiliki peran penting untuk menumbuhkan rasa senang, gairah, dan semangat untuk belajar.

Kurangnya minat belajar pada pembelajaran online disebabkan pada proses pembelajaran online, siswa menjadi kurang aktif dalam penyampaian pendapat dan pemikirannya serta siswa sulit memahami pelajaran melalui pembelajaran online sehingga menyebabkan proses belajar yang membosankan. Apabila siswa mengalami kebosanan dan ketidakminatan dalam belajar maka tidak akan memperoleh kemajuan dalam hasil belajar. Oleh karena itu, diperlukan pendorong dan penyemangat untuk menggerakkan siswa agar semangat belajar sehingga dapat memiliki prestasi belajar yang baik .(R, 2003).

Berdasarkan hasil wawancara dengan siswa di SMP N 3 Tungkal Ulu, minat belajar siswa dalam belajar online pada pelajaran matematika masih rendah. Hal ini dapat ditunjukkan pada saat proses pembelajaran berlangsung seperti halnya ada siswa yang tidak memperhatikan pelajaran, siswa tidak mengikuti kegiatan pembelajaran online, dan masih banyak siswa yang tidak mengerjakan tugas matematika yang di berikan oleh guru. Dari uraian tersebut, maka penulis memandang perlu diadakannya penelitian dengan judul "Pengaruh Lingkungan Belajar dan Minat Belajar Terhadap Hasil Belajar Matematika Siswa Kelas VII Semester Genap SMPN 3 Tungkal Ulu Tahun Ajaran 2020/2021. Penelitian yang sama juga pernah dilaksanakan oleh Nurdianti, dkk dengan judul penelitian Pengaruh Minat dan Lingkungan Belajar peserta didik terhadap hasil belajar. Berdasarkan penelitian tersebut diperoleh terdapat pengaruh positif yang signifikan antara minat belajar dan lingkungan belajar secara Bersama-sama terhadap hasil belajar matematika peserta didik kelas VIII SMP Negeri 1 Kolaka (Nurdianti, Halidin, 2021). Peneliatan lainnya juga dilakukan oleh Indah Prawidia dan Hikmatul Khusna dengan judul penelitian Pengaruh Suasana Lingkungan Belajar dan Minat Belajar Siswa Terhadap Hasil Belajar Matematika. Melalui penelitian tersebut diperoleh hasil secara simultan variabel suasana lingkungan belajar dan minat belajar siswa berpengaruh sebesar 32,3\% terhadap hasil belajar matematika(Indah Prawidia, 2021). Namun karena adanya pandemic COVID 19 yang melanda dunia, dan mempengaruhi aspek pendidikan, maka peneliti tertarik untuk meneliti Kembali pengaruh lingkungan belajar dan minat belajar terhadap hasil belajar matematika siswa Kelas VII di masa pandemi COVID-19.

\section{METODE}

Penelitian ini merupakan penelitian kuantitatif dengan desain non eksperimen. Metode yang digunakan dalam penelitian ini adalah "Ex Post Facto", yang artinya penelitian yang dilakukan untuk meneliti peristiwa tang telah terjadi dan kemudian untuk mengetahui faktor-faktor yang dapat menyebabkan kejadian tersebut. Penelitian ex-post facto menunjukkan bahwa perubahan variabel bebas itu telah terjadi dan peneliti dihadapkan kepada masalah bagaimana menetapkan sebab dari akibat yang 
sedang diamati(Sappaile, 2010). Dalam penelitian ini terdapat tiga variabel yang terdiri dari dua variabel bebas $\left(\mathrm{X}_{1}, \mathrm{X}_{2}\right)$ dan satu variabel terikat $(\mathrm{Y})$. Berdasarkan tujuan dari penelitian ini yaitu untuk mengetahui adakah pengaruhlingkungan belajar siswa dan minat belajar terhadap hasil belajar matematika, maka desain penelitiannya sebagai berikut:

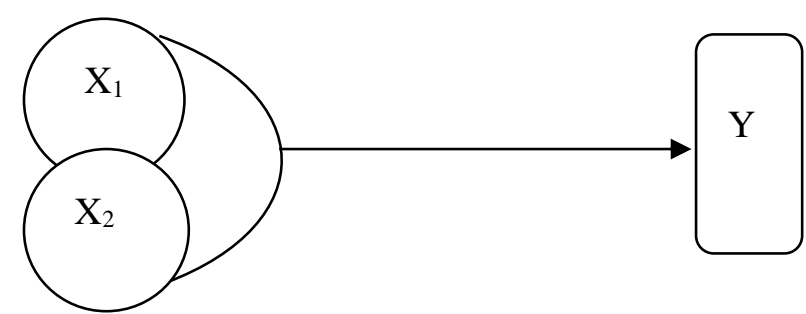

Gambar 1. Skema Hubungan Antara Variabel Bebas dan Variabel Terikat

dengan:

$\mathrm{X}_{1} \quad$ : Lingkungan Belajar sebagai variabel bebas

$\mathrm{X}_{2} \quad$ : Minat Belajar sebagai variabel bebas

Y : Hasil Belajar Matematika sebagai variabel terikat

Penelitian dilaksanakan di kelas VII SMP N 3 Tungkal Ulu. Penelitian dilaksanakan pada Semester Genap Tahun Ajaran 2020/2021. Populasi dalam penelitian ini adalah seluruh siswa kelas VII semester genap SMP N 3 Tungkal Ulu. engambilan sampel dalam penelitian ini menggunakan teknik Random Sampling terhadap kelas, karena objek yang diteliti atau sumber data sangat luas, maka pengambilan sampelnya berdasarkan daerah populasi yang telah ditetapkan. Populasi yang ada yaitu empat kelas, diambil satu kelas secara acak yang digunakan sebagai kelassampel. Diperoleh kelas VII C sebagai kelas sampel penelitian sejumlah 30 siswa. Teknik pengumpulan data pada penelitian ini menggunakan tes dan angket. Teknik analisis data pada penelitian ini terdisi dari analisis uji prasayarat berupa uji normalitas, uji independedn, dan uji linieritas. Uji hipotesis dilakukan dengan analisis regresi berganda.

\section{HASIL DAN DISKUSI}

\section{Pengujian Prasayarat Analisis}

Pengujian prasyarat analisis dilakukan untuk memberikan gambaran sejauh mana asumsi - asumsi prasyarat analisis dapat dipenuhi sesuai dengan teknik analisis data yang telah direncanakan. Uji prasyarat analisis yang dilakukan dalam penelitian ini adalah uji normalitas, uji linieritas, dan uji independen. Berdasarkan hasil uji normalitas diperoleh data bahwa pada variabel lingkungan belajar $\left(\mathrm{X}_{1}\right)$, minat belajar $\left(\mathrm{X}_{2}\right)$, dan hasil belajar matematika $(\mathrm{Y})$ berada pada sebaran data yang normal.

Uji linearitas digunakan untuk mengetahui antara variabel bebas dan variabel terikat mempunyai hubungan linier atau tidak dengan menggunakan rumus regresi linier ( $U j i F)$. Kriteria pengambilan keputusannya adalah hubungan antara variabel $\mathrm{X}$ dan $\mathrm{Y}$ linier apabila $F_{\text {hitung }} \leq F_{\text {tabel }}$, dengan taraf signifikan $5 \%$ dan derajat kebebasan pembilang $\left(v_{1}\right)=k-2$ dan derajat kebebasan penyebut $\left(v_{2}\right)=$ 
$n-k$. Dalam penelitian ini untuk $\mathrm{X}_{1}$ terhadap $\mathrm{Y}$ dengan $v_{1}=17$ dan $v_{2}=11$, untuk $\mathrm{X}_{2}$ terhadap $\mathrm{Y}$ dengan $v_{1}=15$ dan $v_{2}=13$, dan untuk $\mathrm{X}_{3}$ terhadap $\mathrm{Y}$ dengan $v_{1}=15$ dan $v_{2}=13$. Hasil uji linieritas diperoleh data bahwa $\mathrm{X}_{1}$ terhadap $\mathrm{Y}$ dan $\mathrm{X}_{2}$ terhadap $\mathrm{Y}$ disimpulkan linier.

Uji independen digunakan untuk mengetahui ada atau tidak adanya hubungan antara variabel bebas lingkungan belajar $\left(\mathrm{X}_{1}\right)$ dengan variabel bebas minat belajar $\left(\mathrm{X}_{2}\right)$, dengan menggunakan rumus chi-kuadrat. Kriteria pengambilan keputusannya adalah kedua variabel bersifat independen apabila $\chi_{\text {hitung }}^{2} \leq \chi_{\text {tabel }}^{2}$, pada $\alpha=5 \%$ dan derajat kebebasan $(d k)=(B-1)(K-1)$. Dimana B adalah banyaknya baris dan $\mathrm{K}$ adalah banyaknya kolom. Berdasarkan hasil uji independent diperoleh bahwa variabel lingkungan belajar di rumah $\left(\mathrm{X}_{1}\right)$ dengan variabel minat belajar $\left(\mathrm{X}_{2}\right)$ bersifat independent.

\section{Pengujian Hipotesis}

Uji hipotesis yang digunakan adalah analisis regresi. Analisis regresi menyatakan hubungan antara variabel bebas dan variabel terikat. Penelitian ini menggunakan analisis regresi ganda. Dengan analisis ganda diperoleh nilai koefisien korelasi $(R)$ antara lingkungan belajar di rumah dan minat belajar dengan hasil belajar matematika sebesar 0,5728293921. Sehingga di peroleh koefisien determinan $\left(R^{2}\right)$ sebesar 0,3281335125 . Selanjutnya pada pengujian terhadap keberartian koefisien korelasi dengan menggunakan uji- $F$ diperoleh $F_{\text {hitung }}=6,593277831$ sedangkan $F_{\text {tabel }}=3,35$ pada taraf signifikan 5\% dan $v_{1}=2$ dan $v_{2}=27$ sehingga diperoleh $F_{\text {hitung }}>F_{\text {tabel }}$, dengan demikian $H_{0,1}$ ditolak dan $H_{1,1}$ diterima jadi "Ada hubungan yang positif dan signifikan antara lingkungan belajar dan minat belajar dengan hasil belajar matematika siswa kelas VII SMP Negeri 3 Tungkal Ulu Semester Genap Tahun Ajaran 2020/2021". Selain itu diperoleh pula persamaan regresi linear ganda atas $X_{1}$ dan $X_{2}$ adalah $\widehat{Y}=-38,33304331+0,4186176102 X_{1}+0,907019985 X_{2}$.

Berdasarkan uji sumbangan relative (SR) dan sumbangan efektif (SE) masing-masing variabel dapat dilipat pada tabel berikut.

Tabel 2. Hasil Perhitungan Sumbangan Relatif dan Sumbangan Efektif $\left(X_{1}\right.$ dan $\left.X_{2}\right)$

\begin{tabular}{|l|c|c|}
\hline \multicolumn{1}{|c|}{ Variabel } & $\boldsymbol{S R}$ & $\boldsymbol{S E}$ \\
\hline Lingkungan belajar $\left(X_{1}\right)$ & $35,9591 \%$ & $11,7994 \%$ \\
\hline Minat belajar $\left(X_{2}\right)$ & $64,0409 \%$ & $21,01395 \%$ \\
\hline
\end{tabular}

Dari tabel 2 di atas dapat disimpulkan bahwa variabel minat belajar memberikan sumbangan yang paling besar daripada variabel lingkungan belajar.

\section{Diskusi}

Tujuan dari pembahasan hasil penelitian ini adalah untuk mengetahui adanya pengaruh lingkungan belajar $\left(X_{1}\right)$ dan minat belajar $\left(X_{2}\right)$ dengan hasil belajar matematika $(Y)$ siswa kelas VII SMP Negeri 3 Tungkal Ulu Semester Genap Tahun Ajaran 2020/2021. Pada bagian ini dilakukan pembahasan lebih lanjut terhadap hasil penelitian yang dianalisis secara korelasi. Penelitian ini menemukan bahwa hasil uji hipotesis adalah ada pengaruh yang positif dan signifikan antara lingkungan 
belajar dan minat belajar dengan hasil belajar matematika. Dengan kata lain semakin baik lingkungan belajar terhadap belajar anak maka hasil belajar anak juga akan semakin baik. Begitu juga dengan minat belajar anak, semakin tinggi minat belajar anak maka hasil belajarnya pun semakin baik.

Terlebih lagi saat pandemi covid-19 yang berlangsung saat ini, pemerintah memutuskan untuk menerapkan pembatasan pembelajaran sekolah-sekolah mulai dari tingkat paling rendah sampai dengan perguruan tinggi. Pembelajaran dilakukan dari rumah dan melakukan gerakan sosial distancing, dimana orang tua ikut berperan sebagai guru atau pengajar ketika belajar di dalam rumah, orang tua perlu menyiapkan lingkungan belajar yang nyaman. Lingkungan belajar di rumah terhadap anak dalam belajar sangat penting. Karena lingkungan adalah tempat berlangsungnya pendidikan. Lingkungan yang akan memberikan dorongan dan meningkat kan semangat belajar yang dimiliki anak salah satunya meningkatkan minat belajar siswa. Semakin baik minat belajar yang di lakukan siswa maka akan semakin baik pula hasil yang di peroleh.

Penelitian tentang lingkungan belajar dan minat belajar sebelumnya pernah diteliti oleh N.P. E Arya Pratiwi terhadap hasil belajar matematika, yang menyimpulkan bahwa ada pengaruh yang positif antara lingkungan belajar dan minat belajar terhadap hasil belajar matematikadengan $r$ hitung $0,610>r$ table 0,194 demikian juga hasil pengujian dengan uji $\mathrm{f}$ (secara simultan) dengan alpha $=5 \%$ maka dapat diketahui bahwa lingkungan belajar dan minat belajar secara serempak berpengaruh signifikan dengan hasil belajar matematika(Arya Pratiwi, Suarjana, \& Tanggu Renda, 2019).

Dilihat dari penelitian sebelumnya, hal ini sejalan dengan penelitian N.P. E Arya Pratiwi, terdapat pengaruh yang signifikan antara lingkungan belajar dan minat belajar terhadap hasil belajar matematika, berdasarkan hasil penelitian yang dilakukan penulis di peroleh kesimpulan analisis korelasi ganda diperoleh nilai koefisien korelasi ganda $(R)$ sebesar 0,5728293921(Arya Pratiwi et al., 2019). Pada penelitian ini juga diperoleh koefisien determinasi $\left(R^{2}\right)$ sebesar 0,3281335125 artinya $32,81 \%$ hasil belajar di pengaruhi oleh lingkungan belajar siswa dan minat belajar siswa sedangkan sisanya dipengaruhi oleh faktor lain. Adanya variasi hasil belajar matematika $(Y)$ yang dapat dijelaskan oleh lingkungan belajar $\left(\mathrm{X}_{1}\right)$ dan minat belajar $\left(\mathrm{X}_{2}\right)$ melalui garis linier $\widehat{\mathrm{Y}}=-38,333043313+$ $0,4186176102 \mathrm{X}_{1}+0,9070199850 \mathrm{X}_{2}$. Ini berarti kenaikan satu unit $\left(\mathrm{X}_{1}\right)$ mengakibatkan 0,4186 kenaikan $Y$, dan kenaikan satu unit $\left(\mathrm{X}_{2}\right)$ mengakibatkan 0,9070 kenaikan Y. Sedangkan untuk sumbangan relatif $\mathrm{X}_{1}$ sebesar $35,9591 \%$ dan $\mathrm{X}_{2}$ sebesar $64,0409 \%$ serta sumbangan efektif $\mathrm{X}_{1}$ sebesar $11,7994 \%$ dan $\mathrm{X}_{2}$ sebesar $21,01395 \%$.

\section{KESIMPULAN}

Berdasarkan hasil uji analisis regresi ganda setelah melalui uji prasayarat maka dapat disimpulkan bahwa terdapat pengaruh yang positif dan signifikan antara lingkungan belajar di rumah dan minat belajar dengan hasil belajar matematika siswa kelas VII SMP Negeri 3 Tungkal Ulu Semester Genap Tahun Ajaran 2020/2021. Hal ini ditunjukkan dengan uji $-F$ yaitu $F_{\text {hitung }}>F_{\text {tabel }}$ atau $6,593277831>3,35$. Koefisien korelasi ganda $(R)$ sebesar 0,5728293921 dan koefisien determinasi 
$\left(R^{2}\right) \quad$ sebesar 0,3281335125 dengan persamaan garis linear $\widehat{Y}=-38,333043313+$ $0,4186176102 X_{1}+0,9070199850 X_{2}$. Besar sumbangan relatif $X_{1}$ sebesar 35,9591\% dan $X_{2}$ sebesar 64,0409\% serta sumbangan efektif $X_{1}$ sebesar 11,7994\% dan $X_{2}$ sebesar 21,01395\%.

\section{REFERENSI}

Andrini, V. S. (2016). The Effectiveness of Inquiry Learning Method to Enhance Students 'Learning Outcome : A Theoritical and Empirical Review. 7(3), 38-42.

Aprida Pane, M. D. D. (2003). Belajar Dan Pembelajaran. In FITRAH:Jurnal Kajian Ilmu-ilmu Keislaman (Vol. 3). https://doi.org/10.24952/fitrah.v3i2.945

Arya Pratiwi, N. P. E., Suarjana, I. M., \& Tanggu Renda, N. (2019). Korelasi Antara Lingkungan Belajar Dan Minat Belajar Siswa Dengan Hasil Belajar Matematika. Jurnal Penelitian Dan Pengembangan Pendidikan, 3(2), 130. https://doi.org/10.23887/jppp.v3i2.17391

Idola, S., Sano, A., \& Khairani. (2016). Hubungan Antara Persepsi Siswa Tentang Keadaan Lingkungan Fisik Sekolah Dengan Motivasi Belajar. Jurnal EDUCATIO, 2(2), 30-34. Retrieved from http://jurnal.iicet.org

Indah Prawidia, H. K. (2021). Pengaruh Suasana Lingkungan Belajar dan Minat Belajar Siswa Terhadap Hasil Belajar Matematika. Jurnal Penelitian Pembelajaran Matematika, 14(1), 192-207.

MENDIKBUD. Surat Edaran No 4 Tahun 2020 tentang Pelaksanaan Kebijakan dalam Masa Darurat Penyebaran COVID-19. , Pub. L. No. No 4 Tahun 2020, 1 (2020).

Nurdianti, Halidin, F. (2021). Pengaruh Minat dan Lingkungan Belajar Peserta Didik Terhadap Hasil Belajar Matematika. Faktor: Jurnal Ilmiah Kependidikan, 8(1), 20-28.

R, R. (2003). Penerapan Pembelajaran Daring Kombinasi Dalam Meningkatkan Motivasi Belajar Peserta Didik Paket C Vokasi Di Pusat Kegiatan Belajar Masyarakat (Pkbm) Pioneer Karanganyar. In J+Plus Unesa (Vol. 6). Jakarta: Rineka Cipta.

Safari. (2003). Indikator Minat Belajar. In Rineka Cipta.

Sappaile, B. I. (2010). Konsep Penelitian Ex-Post Facto. Jurnal Pendidikan Matematika, 1(2), 105-113.

Slameto. (3004). Belajar dan Faktor-Faktor yang Mempengaruhinya. In Rineka Cipta.

Sukardi, I. (2016). Character Education Based on Religious Values : an Islamic Perspective. 21(1), 4158. 